\title{
Giant suprasellar arachnoid cyst presenting with precocious puberty
}

\author{
Kavya Rao, ${ }^{1}$ Michael L Levy, ${ }^{2}$ John Ross Crawford ${ }^{3}$
}

${ }^{1}$ School of Medicine, UCSD, La Jolla, California, USA

${ }^{2}$ Department of Neurosurgery, University of California San Diego, San Diego, California, USA

${ }^{3}$ Department of Neurosciences and Pediatrics, University of California San Diego, San Diego, California, USA

Correspondence to Dr John Ross Crawford, jrcrawford@ucsd.edu

Accepted 5 August 2014

\section{(a) CrossMark}

To cite: Rao K, Levy ML, Crawford JR. BMJ Case Rep Published online: [please include Day Month Year] doi:10.1136/bcr-2014205750

\section{DESCRIPTION}

A 9-year-old boy presented with a several month history of precocious puberty. Two months before presentation he began to hear his voice gradually deepen; 3 weeks before presentation he noticed increased hair growth over his axillary and genital regions. Review of symptoms was negative for headache, nausea, vomiting or visual changes. In retrospect his growth chart revealed markedly accelerated weight and height over the last year to greater than the 90th centile and his genital examination was consistent with Tanner 3 staging.

MRI revealed a giant $51 \times 52 \times 52 \mathrm{~mm}$ wellcircumscribed suprasellar arachnoid cyst extending to the third ventricular superiorly, the prepontine cistern inferiorly and the parasellar region bilaterally with obstruction of the foramen of Monro and associated ventriculomegaly (figure 1). No transependymal cerebrospinal flow was noted on T2-weighted sequences, suggesting compensated chronic ventriculomegaly. The arachnoid cyst exhibited significant mass effect on the pituitary infundibulum and on the optic chiasm. Given the degree of compression of the optic chiasm and pituitary together with evidence of precocious puberty, an endoscopic cyst fenestration was performed without complication.

Suprasellar arachnoid cysts may present with endocrinopathies months to years prior to development of visual symptoms. ${ }^{1}$ Other presenting symptoms of arachnoid cysts include headache, seizures, visual loss, hydrocephalus or focal neurological deficits corresponding to cyst location. Asymptomatic patients whose arachnoid cysts are incidentally discovered should be observed with serial MRIs, endocrine testing and comprehensive ophthalmological evaluations. ${ }^{2}$ In those patients who are symptomatic, an endoscopic cyst fenestration is the preferred neurosurgical method. ${ }^{3}$

\section{Learning points}

- Suprasellar arachnoid cysts may present as incidental neuroimaging findings or with symptoms such as hormonal changes, headache, seizures and visual loss.

- Patients with asymptomatic suprasellar arachnoid cysts should be routinely followed with serial MRIs, endocrine laboratories and comprehensive ophthalmological evaluations.

- Symptomatic suprasellar arachnoid cysts may be managed surgically with endoscopic cyst fenestration.

\section{Competing interests None.}

Patient consent Obtained.

Provenance and peer review Not commissioned; externally peer reviewed.

\section{REFERENCES}

1 Taylor M, Couto-Silva AC, Adan L, et al. Hypothalamic-pituitary lesions in pediatric patients: endocrine symptoms often precede neuro-ophthalmic presenting symptoms. J Pediatr 2012;161:855-63.

2 Pradilla G, Jallo G. Arachnoid cysts: case series and review of the literature. Neurosurg Focus 2007;22:E7. http://thejns.org/doi/abs/ 10.3171/foc.2007.22.2.7

3 Gangemi M, Seneca V, Colella G, et al. Endoscopy versus microsurgical cyst excision and shunting for treating intracranial arachnoid cysts. J Neurosurg Pediatr 2011;8:158-64.

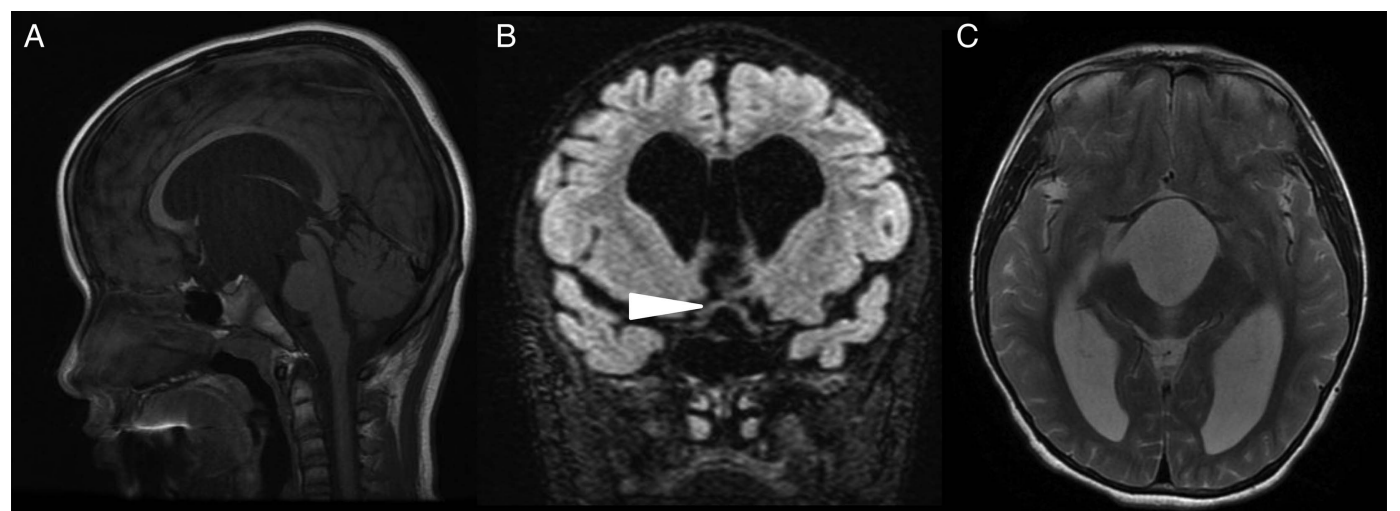

Figure 1 (A) Sagittal T1-weighted MRI reveals a hypointense $51 \times 52 \times 52 \mathrm{~mm}$ suprasellar arachnoid cyst involving the prepontine cistern inferiorly, the parasellar region bilaterally and the third ventricle superiorly with flattening of the pituitary gland and obstruction of the foramina of Monro with associated ventriculomegaly. Coronal CUBE fluid attenuated inversion recovery sequences (B) demonstrate marked bowing of the optic chiasm (arrowhead) and enlargement of the third ventricle seen as marked hyperintensity on T2-weighted sequences (C). 
Copyright 2014 BMJ Publishing Group. All rights reserved. For permission to reuse any of this content visit http://group.bmj.com/group/rights-licensing/permissions.

BMJ Case Report Fellows may re-use this article for personal use and teaching without any further permission.

Become a Fellow of BMJ Case Reports today and you can:

- Submit as many cases as you like

- Enjoy fast sympathetic peer review and rapid publication of accepted articles

- Access all the published articles

- Re-use any of the published material for personal use and teaching without further permission

For information on Institutional Fellowships contact consortiasales@bmjgroup.com

Visit casereports.bmj.com for more articles like this and to become a Fellow 